\title{
Breastfeeding vs. Infant Formula Feed: A Mini Review
}

\author{
Sonali Mohapatra* \\ Department of Biotechnology, Ravenshaw University, Odisha, 753001, India
}

\begin{abstract}
Mothers' milk provides best nutritional need for all infants. As a biologic fluid, it has kinds of benefits like, somatic growth, modulation of postnatal intestinal function, immune ontogeny and development of brain. Despite the fact that breastfeeding is strongly suggested, breastfeeding may not generally be conceivable, appropriate or exclusively sufficient. Infant formula is an industrially made alternative to the breast milk. This paper will guide the parents at the benefits of breastfeeding and answers parent's concerns when they choose the formula milk market by helping in choosing the right one.
\end{abstract}

Keywords: Breast milk, HMO, Colostrum, Transitional Milk, Mature Milk, Foremilk, Hindmilk, Cow Milk-Based Formula, Soy Based-Formula

\section{Introduction}

Breast milk is known as the best source of nourishment of a new born child [1]. Breast milk contains different bioactive agents that alter the gastrointestinal tract function, immune system and development of the brain. Thus, it is otherwise defined as a biological fluid needed for the ideal growth and development of new-born babies. Breastfed babies have a lower risk of getting infections than formula-fed infants.

The World Health Organization (WHO) recommends that mother's milk is the best choice for infants for the first six months of life [2], while The American Academy of Pediatrics (AAP) also recommends breastfeeding for at least 12 months for its unique nutritional, medical and neurodevelopmental benefits for babies [3]. Recently, the Academy of Nutrition and Dietetics confirms their mission that ideal nutrition and good health will be provided by breastfeeding for the first six months of life, and corresponding formula feed along with breastfeeding from six months until at least 12 months of age is the absolute feeding pattern for babies [1].

Breastfeeding is a highly private matter and there are several factors which affects breastfeeding. Only $38 \%$ of babies are breastfed worldwide [4]. In the United States, $75 \%$ babies start breastfeeding from birth, however $67 \%$ infants fed on infant formula when they turn into 3 months [3]. The first 6 months of infant's life are very important in getting an ideal nutrition because improper nutrition can lead to a severe consequence in infant's health. This review article exclusively focuses on the importance of breastfeeding over the infant formula feeding.

\section{Human Breast Milk}

Human breast milk constitutes live cells (blood cells and stem cells) [5], proteins [6], amino acids [7, 8], enzymes and hormones [9], growth factors [10], vitamins and minerals [10], antibodies [11], long chain fatty acids [12], micro RNAs [13], etc. It also contains several bioactive molecules: some of which are protein and lipid derived and indigestible protein-derived like oligosaccharides. Human milk oligosaccharides (HMOs) shows anti-infective properties against pathogens in the gastrointestinal tract of infants [14].

\section{Breast Milk Types}

\section{Colostrum}

It is the first milk produced in the breast after a child's birth. It adds an ideal nutrition for infants. It is highly concentrated, rich in proteins and nutrients, holds low fats and easily digestible. Colostrum plays a vital role in the development of immune system. It protects the babies from getting infection and jaundice [15].

\section{Transitional milk}

*Correspondence to: Sonali Mohapatra, Department of Biotechnology, Ravenshaw University, Odisha, 753001, India, E-mail:precioussonali10@gmail.com

Citation: Mohapatra S (2020) Breastfeeding vs. Infant Formula Feed: A Mini Review. J Pediatr Congenit Dis 6(1): 104. DOI: https://doi.org/10.47275/2379-6707-104.

Received: July 05, 2020; Accepted: July 15, 2020; Published: July 21, 2020

Copyright: (c) 2020 Mohapatra S. This is an Open Access article distributed under the terms of the Creative Commons Attribution 4.0 International License (CCBY) (http://creativecommons.org/licenses/by/4.0/) which permits commercial use, including reproduction, adaptation, and distribution of the article provided the original author and source are credited. 
Breast milk between day 5-14 of the child birth is known as transitional milk [16]. According to Professor Peter Hartmann (a leading authority on breast milk composition) from The University of Western Australia, progesterone (a female hormone) level starts dropping speedily with the delivery of the placenta. As a result, milk synthesis increased and normal composition of breast milk develops and it takes couple of weeks to mature.

\section{Mature milk}

When the new-borne baby turns into 1 month in age, the breast milk is converted into matured milk which is full of protein, sugar, minerals and vitamins and several bioactive compounds like immune cells, enzymes and growth hormones. So, mature milk helps in the growth and development of the infant making him/her healthy [9].

\section{Foremilk and hindmilk}

As the feed continues, the composition of fat increases, because the milk moves through the breast. Towards the end of breastfeeding, the breast milk looks creamier and thicker. This is known as hindmilk and the initial watery milk is called as foremilk. It is a irreversible process in which foremilk can't be turned into hindmilk [16].

\section{Infant Formula}

Breastfeeding is highly recommended, but it may be not possible every time and not suitable everywhere. So, infant formula is an effective substitute which is produced industrially and prepared in a way that it can be very similar with the nutritional composition as in breast milk. There are 3 forms of baby formula: a) Powder- Generally it is in powder form which is mixed with water before feeding, b) Liquid- This is in a concentrated liquid form and is mixed with equal amount of water and c) Ready-to-Feed- It is used as an instant and quick feed formula and requires no mixing.

There are 3 major types of infant formula like cow milk-based formula, soy-based formula and specialized formula. They all differ in nutritional components, calorific value, test and cost.

\section{Cow milk-based formula}

Majority of infant formula are based on Bovine milk which contains higher levels of fat, protein and minerals in comparison to breast milk. So, it must be diluted before feeding $[17,18]$. Cow's milk in the infant diet causes food allergy [19].

\section{Soy based-formula}

They are prepared from soy proteins and useful for infants with congenital lactase deficiency. However, it is seen that, infants who have allergy to cow's milk, also have allergy to soy milk [20].

\section{Specialized formula}

Hypoallergenic formula and amino acid formula are included in the specialized formula. Babies who can't bear cow milk or soy milk they can take protein hydrolysate formula. Amino acid formula with no peptides are prepared for the infants who have serios allergy to cow milk [16].

\section{Formula feed $v s$. breast feed}

\section{Lower respiratory tract infection}

A study by Bachrach and associates in 2003 reported that, infants who were not breastfed faced a 3.6-fold increased risk (95\% CI, 1.9-7.1) of hospitalization for lower respiratory tract infection in the first year of life, compared with infants who were exclusively breastfed for more than 4 months [21].

\section{Gastrointestinal infections}

Several studies found that, babies with formula feed have more risk of getting gastrointestinal problems and diarrhoea. A research by Chien and Howie [22] found that infants who were formula fed or fed a mixture of formula and human milk were 2.8 times (95\% CI, 2.4-3.1) more likely to develop gastrointestinal (GI) infection than those who were exclusively breastfed.

\section{Obesity and metabolic syndrome}

Epidemiologic studies suggest that formulated infants are more likely to become obese or develop type 2 diabetes [23-25]. They have also a risk of getting cardiovascular diseases, high blood pressure and less lipid profiles [25].

\section{Atopic dermatitis}

Infants with a family history of atopy who were exclusively breastfed for less than 3 months have a 1.7 -fold risk of atopic dermatitis ( $95 \%$ CI, 1.1-2.4) compared with infants who are exclusively breastfed [26].

\section{Childhood leukemia}


There are many studies which show associations between formula feeding and childhood leukemia. Kwan and colleagues also found a 1.2-fold higher risk of acute myeloid leukemia (95\% CI, 1.0-1.4) among formula-fed infants compared with infants breastfed more than 6 months [27].

\section{Conclusion}

Although mother's milk is the best option for the infants, it is sometimes unavailable due to some clinical conditions of both mother and child. Infant formulae are a very good option for the child in these scenarios. However, the complications arising from the infant formulae need to be addressed to better fit into the infant and child nutrition.

\section{References}

1. Lessen R, Kavanagh K. 2015. Position of the academy of nutrition and dietetics: promoting and supporting breastfeeding. J Acad Nutr Diet 115(3):444-449. https://doi.org/10.1016/j. jand.2014.12.014

2. 2002. Infant and Young Child Nutrition.

3. Johnston M, Landers S, Noble L, Szucs K, Viehmann L. 2012. Breastfeeding and the use of human milk. Pediatrics 129(3):e827-e841. https://doi.org/10.1542/peds.2011-3552

4. 2014. U.S. Food and Drug Administration Guidance for Industry.

5. Hassiotou F, Geddes DT, Hartmann PE. 2013. Cells in human milk: state of the science. J Hum Lact 29(2):171-182. https://doi.org/10.1177/0890334413477242

6. Beck KL, Weber D, Phinney BS, Smilowitz JT, Hinde K, et al. Comparative proteomics of human and macaque milk reveals species-specific nutrition during postnatal development. $J$ Proteome Res 14(5):2143-2157. https://doi.org/10.1021/pr501243m

7. Zhang Z, Adelman AS, Rai D, Boettcher J, Lonnerdal B. 2013. Amino acid profiles in term and preterm human milk through lactation: a systematic review. Nutrients 5(12):4800-4821. https://doi.org/10.3390/nu5124800

8. Sánchez CL, Cubero J, Sánchez J, Chanclón B, Rivero M, et al. 2009. The possible role of human milk nucleotides as sleep inducers. Nutr Neurosci 12(1):2-8. https://doi. org/10.1179/147683009x388922

9. Hamosh M. 2001. Bioactive factors in human milk. Pediatr Clin North Am 48(1):69-86. https://doi.org/10.1016/s0031-3955(05)70286-8

10. Ballard O, Morrow AL. 2014. Human milk composition: nutrients and bioactive factors. Pediatr Clin North Am 60(1):49-74. https://doi.org/10.1016/j.pcl.2012.10.002

11. Brandtzaeg P. 2010. The mucosal immune system and its integration with the mammary glands. J Pediatr 156(2 suppl):S8-S15.https://doi.org/10.1016/j.jpeds.2009.11.014

12. Uauy R, Mena P, Rojas C. 2000. Essential fatty acids in early life: structural and functional role. Proc Nutr Soc 59(1):3-15. https://doi.org/10.1017/s0029665100000021

13. Alsaweed M, Lai CT, Hartmann PE, Geddes DT, Kakulas F, et al. 2016. Human milk cells and lipids conserve numerous known and novel miRNAs, some of which are differentially expressed during lactation. PLoS One 11(4):e0152610. https://doi.org/10.1371/journal.pone.0152610

14. Gura T. 2014. Nature's first functional food. Science 345(6198):747-749. https://doi.org/10.1126/science.345.6198.747

15. Mitra S, Rennie J. 2017. Neonatal jaundice: aetiology, diagnosis and treatment. Br J Hosp Med (Lond) 78(12):699-704. https://doi.org/10.12968/hmed.2017.78.12.699

16. Martin CR, Ling PR, Blackburn GL. 2016. Review of infant feeding: key features of breast milk and infant formula. Nutrients8(5):279.https://doi.org/10.3390/nu8050279

17. Koletzko B, Baker S, Cleghorn G, Neto UF, Gopalan S, et al. 2005. Global standard for the composition of infant formula: recommendations of an ESPGHAN coordinated international expert group. J Pediatr Gastroenterol Nutr 41(5):584-599. https://doi.org/10.1097/01.mpg.0000187817.38836.42

18. Cook DA. 1989. Nutrient levels in infant formulas: technical considerations. J Nutr 119(12 Suppl):1773-1777. https://doi.org/10.1093/jn/119.suppl_12.1773

19. Hochwallner H, Schulmeister U, Swoboda I, Spitzauer S, Valenta R. 2014. Cow's milk allergy: from allergens to new forms of diagnosis, therapy and prevention. Methods66(1):22-33. https://doi.org/10.1016/j.ymeth.2013.08.005

20. 2015. U.S. National Library of Medicine Infant Formulas-Overview.

21. Bachrach VRG, Schwarz E, Bachrach LR. 2003. Breastfeeding and the risk of hospitalization for respiratory disease in infancy: a meta-analysis. Arch Pediatr Adolesc Med 157(3):237243.https://doi.org/10.1001/archpedi.157.3.237

22. Chien PF, Howie PW. 2001. Breast milk and the risk of opportunistic infection in infancy in industrialized and non-industrialized settings. Adv Nutr Res 10:69-104. https://doi. org/10.1007/978-1-4615-0661-4_4

23. Ip S, Chung M, Raman G, Chew P, Magula N, et al. 2007. Breastfeeding and maternal and infant health outcomes in developed countries. Evid Rep Technol Assess (Full Rep) (153):1186

24. Horta BL, Bahl R, Martinés JC, Victora CG.2007. Evidence on the long-term effects of breastfeeding: systematic review and meta-analyses. Geneva: World Health Organization. 1-57.

25. Harder T, Bergmann R, Kallischnigg G, Plagemann A. 2005. Duration of breastfeeding and risk of overweight: a meta-analysis. Am J Epidemiol 162(5):397-403. https://doi.org/10.1093/ aje/kwi222

26. Gdalevich M, Mimouni D, David M, Mimouni M. 2001. Breast-feeding and the onset of atopic dermatitis in childhood: a systematic review and meta-analysis of prospective studies. $J$ Am Acad Dermatol 45(4):520-527. https://doi.org/10.1067/mjd.2001.114741

27. Kwan ML, Buffler PA, Abrams B, Kiley VA. 2004. Breastfeeding and the risk of childhood leukemia: a meta-analysis. Public Health Rep 119(6):521-535. https://doi.org/10.1016/j. phr.2004.09.002 